\title{
IAMJ
}

INTERNATIONAL AYURVEDIC MEDICAL JOURNAL

\section{A COMPARATIVE CLINICAL STUDY OF PANCHTIKTA KSHEERA BASTI AND ASTHI SANDHANIYA DRAVYA SIDDH KSHEERA BASTI IN ASTHI KSHAYA (OSTEOPOROSIS)}

\author{
Sunita Bola ${ }^{1}$, Mahesh Kumar Sharma ${ }^{2}$, Gyan Prakash Sharma ${ }^{3}$ \\ ${ }^{1}$ P.G. Scholar, P.G. Department of Panchkarma, \\ ${ }^{2}$ M.D. (Ayu). Associate Professor \& Head of Panchkarma Department, \\ ${ }^{3}$ M.D.(Panchkarma) Assistant professor of Panchkarama Department. \\ Dr. S. R. Rajasthan Ayurved University Jodhpur, Rajasthan, India
}

Corresponding Author: sbola2012@gmail.com

https://doi.org/10.46607/iamj02p5012020

(Published online: November 2020)

Open Access

(C) International Ayurvedic Medical Journal, India 2020

Article Received: 30/10/2020 - Peer Reviewed: 10/11/2020 - Accepted for Publication: 16/11/2020

Check for updates

\begin{abstract}
According to Ayurveda, diseases occur due to Dhatuvaishamyta \& Dhatusamya maintains regularity. The Ashti Dhathu is the one consecrated with the role of Shareera Dharana among the Saptha Dhathus. Asthikshaya is the condition in which there is Kshaya of Asthi Dhatu. Asthi Kshaya may be compared to Osteoporosis, in which there is a decrease in bone mass leading to bone brittleness and fractures. Asthi Kshaya is one of Dhatu Kshaya. Due to Dhatu Kshaya there will be Vata Prakopa hence in the treatment decreased Vata Dosha along with nourishing Asthi Dhatu essential. Basti is considered as the best Treatment for the Vata Dosha and Asthi Ashrita Vyadhi and is known as Ardhachikitsa in Ayurveda. Ksheera Basti nourished the Asthi Dhatu and pacified there its Asharya Vata Dosha. Aim \& Objective- To assess the efficacy of Panchtikta Ksheera Basti and Asthi Sandhaniya Dravya Siddh Ksheera Basti in the management of Osteoporosis. Material and Methods- Present study was undertaken on 30 patients of Osteoporosis. Patients diagnosed Osteoporotic by Bone Mineral Density test, were randomly divided into two Groups, A and B consisting of 10 patients each. Conclusion- The study shows that the Panchtikta Ksheera Basti and Asthi Sandhaniya Dravya Siddh Ksheera Basti are very effective in the management of Osteoporosis.
\end{abstract}


Keywords: Asthi Kshaya, Osteoporosis, Ksheera Basti, Bone Mineral Density.

\section{INTRODUCTION}

According to Ayurveda, freedom from diseases is not only health. To be healthy, a person should be happy by mentally, physically, socially and also spitefully. Imbalance of Dosha is termed as Roga. Amongst in Tridosha Vata is responsible for almost all illnesses. The Ashti Dhathu is the one consecrated with the role of Shareera Dharana among the Saptha Dhathus. Asthi Dhatu is the one Dhathu which gives the body a profile and protects the organs which are imperative. Without Asthi Dhatu the soft tissue bolus would have been nebulous. Therefore, Asthi Dhatu can specifically be called the bars of building, on which man stands tall and beautiful in a systematic structure. Every instability in the dhatus equilibrium contributes to irregularities in the Sharira. Asthikshaya is the condition in which there is Kshaya of Asthi Dhatu. If an individual takes AaharVihar Vatavardhak then the body's Vat Dosha is aggravated and Kshaya of Asthi. When Vata and Asthi have Aashrya-Aashryi Bhava ${ }^{1}$ between them Asthis were directly influenced by vitiation of Vata. According to which there is an intimate connection between Asthi Dhatu and Vata Dosha. Asthi Dhatu and Vata Dosa are inversely proportional to each other i.e. the former diminishes when the latter is increased. The Symptoms of Asthi Kshaya are Asthishula, Toda, Sandhi Shaithilya, Kesha, Loma, Nakha, Danta Vikara and Patana, Dourbalya, Rukshata ${ }^{2}$ etc. The Chikitsa Sutra of Asthikshaya directly described by Acharya Vagbhata and Acharya Charaka, The Basti along with Ksheera, Ghrita and Tikta Rasa should be given in management of Asthikshaya $a^{3}$. In modern science, osteoporosis is described as "a progressive systemic skeletal disease characterized by low bone mass and micro-architectural weakening of bone tissue, resulting in increased bone fragility and fracture susceptibility. ${ }^{4}$ " Osteoporosis is a rising global public health epidemic. Between the middle age on a significant proportion of the population is at risk of experiencing a fracture during their remaining lifespan. According to the International Osteoporosis Foundation's Osteoporosis fact sheet, there are 1 out of 8 males and 1 out of 3 females suffering from osteoporosis in India. India one of the world's largest affected countries.

The treatment administered in modern medical science included supplementation of calcium and vitamin-D, hormone replacement therapy (HRT), and use of other medicines such as bisphosphonates, oestrogen receptor selective modulators (SERMS), etc ${ }^{5}$. Yet it has not achieved the desired result Thus, it is our responsibility as students of great Ayurvedic science to offer a lasting solution to this global problem. Ayurveda is ancient medical sciences of the world. Since it is a disease caused by the aggravation of Vata so that treat pioneer treatment for Vatic disorders is Basti Karma so that Panchtikta Ksheera Basti was selected as per the principal for the treatment of Asthivikara told by Acharya Charak. Asthi Sandhaniya Dravya Siddh Ksheera Basti was tried due to its Rasayana and its indication in Asthi Bhagna and strengthening of bone.

\section{Aim \& Objective}

1. To study the conceptual and clinical aspects of the diseases Asthikshaya/Osteoporosis as Per Ayurveda and modern sciences.

2. To evaluate the effect of Panchtikta Ksheera Basti in Asthiksahya.

3. To evaluate the effect of Asthi Sandhaniya Darvya Siddh Ksheera Basti in Asthiksahya w.s.r. to osteoporosis

4. To study in detail about Basti.

Material and Methods: -

Selection of cases: Total 30 patients of osteioporosis \& Osteopenia (Asthikshaya) were registered on the bases of syptoms \& relevant B.M.D test in camps organized at panckarma department, DSRRAU JODHPUR by Aimil Pharmaceuticals Private limited on 4/2/2020.

Grouping of Patients: After complete examination and investigation, 30 Patients will be Divided randomly in two groups (15 Patients in each group) irrespective of sex and age group in between 40-70 years.

Group A: Will be given Panchtikta Ksheera Basti for 16 days. 
Group B: Will be given Asthi Sandhaniya Darvya Siddh Ksheera Basti for 16 day.

\section{Inclusive Criteria:}

1. Patients will be selected between the age group of 40-70 years.

2. Patient representing with classical features of $A s$ thikshaya.

3. Patient of both sex are taken.

4. Patient of osteoporosis diagnosed by BMD test.

\section{Exclusive Criteria:}

1. Patient below the age of 40 and above 70 years.

2. Patient suffering from any systemic disorder like DM, HTN, Endocrinal disorders, Paget's disease, Cushing syndrome etc.

3. Patient suffering from pathological osteoporosis or any neoplasm or osteoporosis related to systemic disorders.

4. Osteoporosis associated with fracture.

5. Patients who were unfit for Basti karma.

\section{Assessment Criteria:}

Table 1: Subjective Parameter

\begin{tabular}{|c|c|c|}
\hline Parameters & & Score \\
\hline \multirow[t]{5}{*}{ 1.Asthi Shoola (Bone pain) } & No pain & 00 \\
\hline & Mild pain after movement $\&$ subside by rest & 01 \\
\hline & Moderate degree of pain, no relief by rest but not disturbing sleep or other activities & 02 \\
\hline & Severe degree of pain disturbing sleep or routine activities & 03 \\
\hline & Severe degree of pain disturbing sleep or routine activities and relieved by analgesic. & 04 \\
\hline \multirow[t]{5}{*}{ 2. Sandhi Saithilyata } & Pain & 00 \\
\hline & Pain and Swelling & 01 \\
\hline & $\begin{array}{l}\text { Pain++ } \\
\text { Swelling++ }\end{array}$ & 02 \\
\hline & $\begin{array}{l}\text { Pain+++ } \\
\text { Swelling+++ } \\
\text { Crepitus }+\end{array}$ & 03 \\
\hline & $\begin{array}{l}\text { Pain++++ } \\
\text { Swelling++++ } \\
\text { Crepitus }++ \\
\text { Tenderness }+\end{array}$ & 04 \\
\hline \multirow{5}{*}{$\begin{array}{l}\text { 3.Sparsashayata (Tender- } \\
\text { ness) }\end{array}$} & No tenderness & 00 \\
\hline & Mild (tenderness on pressure) & 01 \\
\hline & Moderate Wincing of face on pressure & 02 \\
\hline & Severe (Wincing of face\& withdrawal of affected part on pressure) & 03 \\
\hline & Intolerable (resist slightest of pressure) & 04 \\
\hline \multirow{5}{*}{$\begin{array}{l}\text { 4.Dourbalya/Shrama (Gen- } \\
\text { eral debility) }\end{array}$} & No & 00 \\
\hline & Not able to perform strenuous activity & 01 \\
\hline & Not able to perform moderate strenuous activity & 02 \\
\hline & Can perform mild activity without help & 03 \\
\hline & Can perform mild activity & 04 \\
\hline \multirow[t]{5}{*}{ 5. Keshapatan (Hair Fall) } & No History of Kesapatana & 00 \\
\hline & Mild hair loss observed recently & 01 \\
\hline & Mild to moderate hair loss observed recently & 02 \\
\hline & Moderate hair loss since long time & 03 \\
\hline & Severe hair loss & 04 \\
\hline 6.Rukshya (Dryness) & No dryness & 00 \\
\hline
\end{tabular}




\begin{tabular}{|l|l|}
\hline Dryness during winter disappear after applying moisturizer. & 01 \\
\hline Dryness during winter, but no longer effect of moisturizer. & 02 \\
\hline Dryness during winter, but no effect of moisturizer. & 03 \\
\hline Dryness during humid climate no effect of moisturizer. & 04 \\
\hline
\end{tabular}

Objective Criteria: Bone Mineral Density (W.H.O. criteria for osteoporosis)

Table 2: T-score

\begin{tabular}{|l|l|l|}
\hline S.no & Category & (BMD) Score \\
\hline 1. & Normal & -1 \\
\hline 2. & Osteopenia & -1.1 to- -2.5 \\
\hline 3. & Osteoporosis & Less than or equal to -2.5 \\
\hline 4. & Severe osteoporosis & Less than -2.5 with fracture \\
\hline
\end{tabular}

Table 3: Overall effect of therapies

\begin{tabular}{|l|l|}
\hline Cured & $100 \%$ relief in sign and symptoms \\
\hline Marked improvement & $>75 \%$ relief in sign and symptoms \\
\hline Moderate improvement & 51 to $75 \%$ relief in sign and symptoms \\
\hline Mild improvement & 25 to $50 \%$ relief in sign and symptoms \\
\hline No Improvement & Below $25 \%$ \\
\hline
\end{tabular}

\section{Plan of Treatment:}

1. Local Abhyanga with Murchit Tila Taila on Kati, Vakshana, Pakvashya region was administered.

2. Local Swedna on Kati, Vakshana, Pakvashya region was administered.

3. Basti: (16 days).

Ingredients of Trial Drug- Panchtikta Ksheera Basti (400 ml)

1. Panchtikta Ghrit -1 Prasurta $(80 \mathrm{ml})$

2. Tila Taila -1 Prasurta $(80 \mathrm{ml})$

3. Ksheera - 2 Prasurta $(160 \mathrm{ml})$

4. Madhu - 1 Prasurta $(80 \mathrm{ml})$

5. Saindhva Lavana - 3 gm

6. Kalka (Satpuspa, Ajvayan, Pippali) - 20 gm

Ingredients of Trial Drug - Asthi Sandhaniya Darvya Siddh Ksheera Basti (480 ml)

1.i.) Kawath Darvya -

Mulethi, Guduchi,

Prasanprani,Patha,

Majistha,Dhatki, Priyangu

,Lodhra, Katphala,

Mocharasha.

ii.) Ksheera:

\begin{tabular}{|l|} 
Each Kwatha \\
Darvya in same \\
quantity (30 gm \\
Total Matra) and \\
Made. \\
Ksheerpaka $(240$ \\
$\mathrm{ml})$
\end{tabular}

2. Kalka Darvya - Satpuspa, Ajvayan, Pipple, Rasna $40 \mathrm{gm}$

3. Madhu- $80 \mathrm{ml}$

4. Saindhva Lavana - 3 gm

5. Ghrit - $60 \mathrm{ml}$

6. Tila Taila $-60 \mathrm{ml}$

\section{Observation:}

- In case of demographic data, majority of patients i.e. the highest was seen in age group of 40-50 years, Housewives, Urban area, Middle class, Vegetarian dietary habit, Illiterate patients. Majority of the Patients i.e. $60 \%$ were having Krura Koshtha and $46.66 \%$ were having Vishamagni. That most of the patients $30 \%$ in this study have maximum chronicity in $0-1$ years. trial maximum $86.66 \%$ patients were addicted to tea/coffee, $68.42 \%$ patients had Menopause.

- $46.67 \%$ patients were having Vata-Pittaja Sharirika Prakriti, $36.67 \%$ patients were having Madhyama Saara, 63.33\% were on Madhyama Satmya $60 \%$ patients were found to have Madhyama Samhanana, 63.33\% were of Madhyama Satva, 33.33 $\%$ had Madhyama Vyayama Shakti, 50.00\%) had Madhyama Nidra Pravarti. 19 (63\%) taken Katu, Tikta Aahara, and 18 (60\%) patients taken Rooksha 
Aahara, 13 (43\%) patients taken Laghu Aahara and 7 (23\%) patients taken Sheeta Aahar.

- $100 \%$ Patients had Prasrista Vit, Mootra, Smeerana and 90\% patients had Agni Dipti Lakshana, 86.66\% patients had and Ashaya Laghuta, 76.66\% Patients had Ruchi Vriddhi Lakshana.

- Pratyagaman Kala of Panchtikta Ksheera Basti: Out of 15 patients Maximum $66.66 \%$ had Time of expulsion 20-40 minute.
- Pratyagaman Kala of Asthi Sandhaniya Dravya Siddha Ksheera Basti: - Out of 15 patients Maximum $73.33 \%$ had Time of expulsion 0-20 minute.

- No side effect was reported by any of the patients during the course of therapy. All the patients tolerated Panchkarma procedure very well.

\section{Results:}

Table 4: Showing effect of therapy in Subjective Parameters (Wilcoxon matched pairs signed rank test):

\begin{tabular}{|c|c|c|c|c|c|c|c|c|c|}
\hline \multirow[t]{2}{*}{ Sign \& Symptoms } & \multirow[t]{2}{*}{ Gr. } & \multicolumn{2}{|c|}{ Mean score } & \multirow[t]{2}{*}{ Difference } & \multirow{2}{*}{$\begin{array}{l}\% \\
\text { Relief }\end{array}$} & \multirow[t]{2}{*}{$\mathbf{S . D} \pm$} & \multirow[t]{2}{*}{ S.E \pm} & \multirow[t]{2}{*}{ P value } & \multirow[t]{2}{*}{ Result } \\
\hline & & BT & $\mathbf{A T}$ & & & & & & \\
\hline \multirow{2}{*}{$\begin{array}{l}\text { Asthi Shoola } \\
\text { (Bone Pain) }\end{array}$} & $\mathbf{A}$ & 2.533 & 0.8000 & 1.733 & $68.42 \%$ & 0.7988 & 0.2063 & 0.0001 & E.S. \\
\hline & B & 2.467 & 0.8667 & 1.600 & $64.86 \%$ & 0.7368 & 0.1902 & $<0.0001$ & E.S. \\
\hline \multirow[t]{2}{*}{ Sandhi Saithilyata } & $\mathbf{A}$ & 2.867 & 1.133 & 1.733 & $60.47 \%$ & 0.5936 & 0.1533 & $<0.0001$ & E.S. \\
\hline & B & 2.600 & 1.200 & 1.400 & $53.85 \%$ & 0.5071 & 0.1309 & $<0.0001$ & E.S. \\
\hline \multirow{2}{*}{$\begin{array}{l}\text { Sparsashayata } \\
\text { (Tenderness) }\end{array}$} & $\mathbf{A}$ & 2.533 & 1.133 & 1.400 & $55.26 \%$ & 0.5071 & 0.1309 & $<0.0001$ & E.S. \\
\hline & B & 2.200 & 1.067 & 1.133 & $51.52 \%$ & 0.6399 & 0.1652 & 0.0001 & E.S. \\
\hline \multirow{2}{*}{$\begin{array}{l}\text { Dourbhalya } \\
\text { /Sharma } \\
\text { (General Debility) }\end{array}$} & $\mathbf{A}$ & 2.800 & 0.7333 & 2.067 & $73.81 \%$ & 0.5936 & 0.1533 & $<0.0001$ & E.S. \\
\hline & B & 2.733 & 1.000 & 1.733 & $63.41 \%$ & 0.7988 & 0.2063 & $<0.0001$ & E.S. \\
\hline \multirow[t]{2}{*}{ Keshapatan (Hair Falling) } & $\mathbf{A}$ & 2.200 & 1.133 & 1.067 & $48.48 \%$ & 0.8837 & 0.2282 & 0.0010 & E.S \\
\hline & B & 1.733 & 1.200 & 0.5333 & $30.77 \%$ & 0.6399 & 0.1652 & 0.0078 & V.S. \\
\hline \multirow{2}{*}{$\begin{array}{l}\text { Rukshya } \\
\text { (Dryness) }\end{array}$} & $\mathbf{A}$ & 2.400 & 1.000 & 1.400 & $58.33 \%$ & 0.8281 & 0.2138 & 0.0001 & E.S. \\
\hline & B & 1.800 & 0.9333 & 0.8667 & $48.15 \%$ & 0.7432 & 0.1919 & 0.0010 & E.S \\
\hline
\end{tabular}

Table 5: Showing effect of therapy in Objective Parameters BMD: t-score (Paired ' $T$ ' Test):

\begin{tabular}{|c|c|c|c|c|c|c|c|c|c|c|}
\hline & \multirow[t]{2}{*}{ Gr. } & \multicolumn{2}{|c|}{ Mean score } & \multirow{2}{*}{$\begin{array}{l}\text { Differ- } \\
\text { ence }\end{array}$} & \multirow{2}{*}{$\begin{array}{l}\text { \% } \\
\text { Relief }\end{array}$} & \multirow[t]{2}{*}{ S.D \pm} & \multirow[t]{2}{*}{ S.E \pm} & \multirow[t]{2}{*}{ P value } & \multirow[t]{2}{*}{ T value } & \multirow[t]{2}{*}{ Result } \\
\hline & & BT & AT & & & & & & & \\
\hline BMD & $\mathbf{A}$ & -2.180 & -1.500 & -0.6800 & $31.19 \%$ & 0.2833 & 0.07316 & $<0.0001$ & 9.295 & E.S \\
\hline t- score & B & -2.820 & -2.073 & -0.7467 & $26.48 \%$ & 0.4549 & 0.1175 & $<0.0001$ & 6.357 & E.S \\
\hline
\end{tabular}

Inter Group Comparison of Effect of Therapies: -

Table 6: Showing Inter Group comparison in Subjective Parameters (Maan-Whitney):

\begin{tabular}{|l|l|l|l|l|l|l|}
\hline S.no & Subjective parameter & Mean diff. Group A & Mean diff. Group B & MW-U & P-Value & Result \\
\hline 1. & Asthi Shoola (Bone Pain) & 1.733 & 1.600 & 96 & 0.2198 & N.S \\
\hline 2. & Sandhi Saithilyata & 1.733 & 1.400 & 79.50 & 0.0628 & N.Q.S \\
\hline 3. & Sparsashayata (Tenderness) & 1.400 & 1.333 & 88.50 & 0.1298 & N.S \\
\hline 4. & $\begin{array}{l}\text { Dourbhalya } \text { Sharma } \\
\text { (General Debility) }\end{array}$ & 2.067 & 1.733 & 82.50 & 0.1822 & N.S \\
\hline 5. & $\begin{array}{l}\text { Keshapatan } \\
\text { (Hair Falling) }\end{array}$ & 1.067 & 0.5333 & 74 & 0.0455 & S. \\
\hline 6. & Rukshya (Dryness) & 1.400 & 0.8667 & 73 & 0.0423 & S. \\
\hline
\end{tabular}


Table 7: Showing Inter Group comparison in Objective Parameters (Unpaired t Test)

\begin{tabular}{|l|l|l|l|l|l|}
\hline Objective Parameter & Mean diff. Group A & Mean diff. Group B & T value & P value & Result \\
\hline BMD t score & -0.6800 & -0.7467 & 0.4818 & 0.3169 & N.S \\
\hline
\end{tabular}

Table 8: Total Effect of Therapy in the Patients of Asthikshaya (Osteoporosis)

\begin{tabular}{|l|l|l|l|l|}
\hline & GROUP A (15 Patients) & $\%$ & GROUP B (15 Patients) & $\%$ \\
\hline Cured & 0 & $0 \%$ & 0 & $0 \%$ \\
\hline Marked improvement & 3 & $20 \%$ & 2 & 13.33 \\
\hline Moderate improvement & 10 & $66.66 \%$ & 8 & $53.33 \%$ \\
\hline Mild improvement & 2 & $13.33 \%$ & 5 & $33.33 \%$ \\
\hline No Improvement & 0 & $0 \%$ & 0 & $0 \%$ \\
\hline
\end{tabular}

Graph 1: Showing the Effect of therapy on Subjective Parameter in Group A

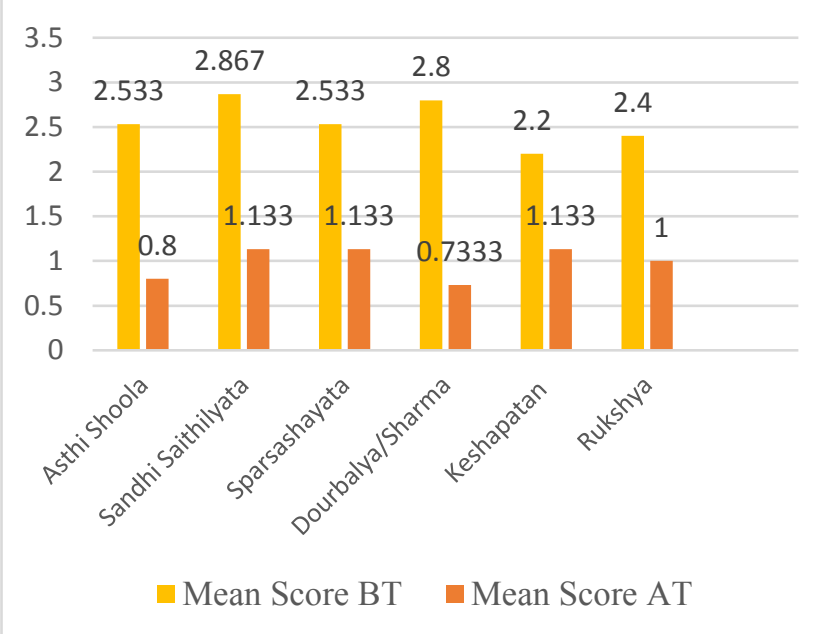

\section{DISCUSSION}

Mode of action of therapy: Basti Karma was selected as per the principal told by Acharya Charka and it was given in the form of a Yapana Basti, Yapana Basti perform dual function both Anuvasana and Nirhua. Yapana Bastis are Mridu and Brimhana in action, they promote Dhatu homeostasis and perform mild Shodhana also. These Bastis are Mridu as it contains milk. Ghee and Madhu. These stays for a long time in Pakvashaya and can be administered at any time. The Reason behind selection Since it is a disease caused by the aggravation of Vata so that treat pioneer treatment for Vatic disorders is Basti Karma and Basti Karma is called Ardhachikitsa ${ }^{6}$ in Ayurveda. Charaka and Hemadri said Basti is useful for the Kshina Dhatus and Bhagna (fractures) of the Asthi and Sandhi. The action of Basti
Graph 2: Showing the Effect of therapy on Subjective Parameter in Group B

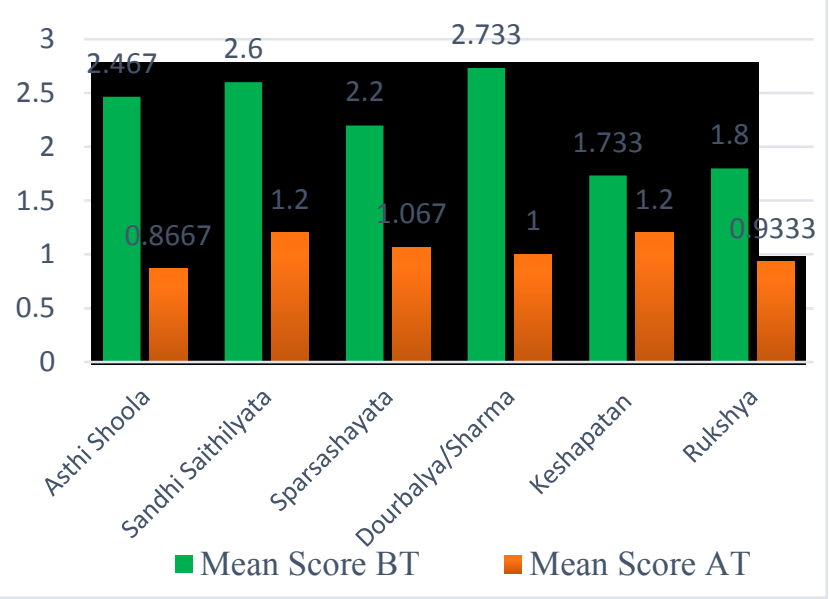

on Asthivaha Srotas and Majjavaha Srotas is also seen as beneficial effects. According to Acharya Sushruta ${ }^{7}$ Virya of Basti administered into Pakvashaya reaches the whole body through the channels (Srotasa), as the active principles in the water when poured at the root of the tree reaches the whole plant. According to Acharya Charaka \& Vagbhatta the treatment of Asthikshaya is Basti Karma using Tikta Rasatmaka Aushadhi Dravya along with Ghrit and Ksheera. Panchtikta Ksheera Basti has nourishing factor for Asthi Dhatu in the form of Tikta drugs, milk, honey, Ghee and mitigates Vata-Pitta and maintains stability of Kapha. According to Arundata ${ }^{8}$ the constituent having Snighda and Shoshana properties and produced Khartwa and rises Asthi, as Asthi is also Khara by Guna.There is no such combination present in any Single Dravya which 
have both Singda and Shoshana properties. Therefore Tikta Rasa have Sosana Guna. Ksheera and Ghrita, which are Singdha in Guna and advised to be used with the constituent which are Tikta and have Shoshana property. So that Ksheera or Ghrita should be used together in the form of Ksheera Basti. Ksheera, Ghrita is Vata Shamak and Tikta Rasa due to its composition of Panchamahubhut and Khara, Soshana Guna will increase of Asthi Dhatu. The combination of Ksheera, Ghrita and Tikta Dravyas Siddh Basti which are good at Vatasamana and Asthiposhana. The combination of Snigdha and Sosana Gunas which produce Khara Guna and does the Vrddhi of Asthi Dhatu and repairing the degenerative change in Asthi and delaying the degenerative change in Asthi and prevent of Asthikshaya. Asthi are Panchbhoutika in nature. The weight and Sthira in the Asthis indicates its Prathiv nature, colour of Asthi indicates Tejas Mahabhoot, Snigadhata indicates Jala Mahabhoot, cavities inside the bones indicate Aakash Mahabhoot and movements inside indicates Vayu Mahabhoota in the bones. In Both Basti Tikta and Kasaya drugs are Vayu, Aakash and Prithvi Mahabhoota dominate, milk, Ghrita, Taila and honey are Prithvi, Jala Mahabhoota dominate and Kwath is formed due to Agni Samyog, so we can say that Panchbhoutik nature of Both Basti matched with Panchbhoutik nature of Asthis and this factor also played a role in alleviating the symptoms of Asthikshaya. It is in accordance with the principal told by Acharya Sushrut for the treatment of Kshayas i.e. Swayoni Vardhanam Pratikarah. Ksheera Basti nourishes the Asthi Dhatu and there by pacifies its Ashrayee Vata Dosha. Several of Ksheera Basti components, such as Sneha, help to Formation of Asthi and Majja Dhatu, thus preventing bone degeneration and osteoporosis. Most joint disorders occur due to calcium deficiency, so calcium levels can be increased in the body by administering Ksheera Basti. According to modern science calcium is excreted through the stools which is important ingredients of bones. Where bone ingredients are excreted through the stools. The implanted medicine into the colon could reach the bone. Particularly we can see that bone pain in Asthikshaya probably subsides with Tikta Ksheera Basti administration.
So that Ksheer and Ghrit, which have properties of Madhur and Snigdha, used with Tikta,Kasaya Dravayas which have properties of Shoshan. Ksheer and Ghrit pacify the Vata and Pitta, and act as a Karma of Brimhana. Getting, Saindhav lavana having Sukshamguna reaches up to the body's micro channels ${ }^{9}$. Because of the common composition of Panchabhoutika components of Panch Tikta Ksheer Basti and Asthi, these components will enter the Asthivaha Srotas and will be implemented by the Parthiwagni, Vayavyagni and Tejasagni and transformed into Asthi Poshakamshas on which the Asthi Dhatwagni will act and convert into Sthayi Asthi Dhatu ${ }^{\mathbf{1 0}}$. Hence there will be increased of the Asthi Dhatu. Phytogenic molecules (derived from plants of Tikta Rasa Pradhana and from dairy products) have estrogenic action that reduce osteoclastic activity and increase the development of bone matrix and mineral deposition, thus helping to prevent osteoporo$\operatorname{sis}^{11}$.

Calcium deficiency also decreases the bone density and induces bone degeneration. The best source of calcium and other minerals is cow's milk. Calcium is consumed from duodenum by carrier-mediated active transport and by facilitated diffusion from the rest of the small intestine ${ }^{\mathbf{1 2}}$. Thus, through Ksheera Basti increasing the calcium level in the body, and restoring the bony tissue. The Ksheer Basti enters the Pakwashaya which is also Purishdhara Kala, and according to Dalhana Purishdharakala there was nothing but Asthidhara Kala so there is a definite relationship between these two Kalas. So, when the components of Basti i.e., Ksheera, Ghrita and Madhu nourishment the Purishadhara Kala, they nourish the same Asthidhara Kala and it is detected that the symptoms of pain and tenderness are reduced.

Mode of action of Drug: Pnchtikta dravya have mainly Tikta Rasa and Tikta Rasa is Vata aggravated Dravya but Tikta Rasa is Asthi Vriddhikara because Tikta Rasa is mainly Aakash \& Vayu Mahabhuta Pradhan Dravya. Tikta Rasa has tendency to go towards Asthi Dhatu hence which has same Mahabhautika Tattva. They tend to reach the palace (tissues and organs) rich in Akash and Vayu elements by virtue of these elements. All Srotas consist of Akash Mahabhuta. 
Hence the Tikta Ksheer Basti has maximum affinity to the bone tissue and bone channels. In Asthi Sandhaniya Darvya Siddh Ksheera Basti used Sandhaniya Mahakashya $^{\mathbf{1 3}}$ form of Kawatha all the Sandhaniya Dravya is mainly Kasaya Rasa Pradhana so that Kasaya Dravya have proparty of Sandhan all over Dhatus due to constriction. The Dravya that are helpful for uniting tissues, wound healing and treatment of fracture are called Sandhaniya which Sandhana in nature and prevent Bhagna of Asthi It promotes the union of interrupted Dhatus.

Vitamin-D found in cow's milk helps in bone development by preserving the proper calcium levels in the blood along with the parathyroid hormone. Vitamin-K stimulates osteocalcin in the bone which is the main non-collagen protein. Inside the bone, osteocalcin aches, calcium molecules. Cow's milk also contains lactoferrin, an iron-binding protein that enhances osteoblast growth and function, bone-building cells and decreases the rate at which these cells die by up to 50 $70 \%$. They also reduce osteoclast formation, the cells responsible for bone breakdown, thereby helping to build the bone and preventing osteoporosis. In this Basti, Tila Taila is used as Sneha, it is mixed with the solution of honey (Madhu) and Saindhava and helps in forming a uniform mixture. Sneha increases the permeability of cell membrane and become helpful in elimination of Dosha ana Mala Because of its Guru, Snighda Guna it liquefies the Dosha and breakdowns the compacts Mala. Apart from these functions it also protects the mucus membrane from the untired effects of irritating drugs in the Basti Dravya. Ghee is used as a carrier or "Yogavahi" because of its supreme penetrating qualities and thus ability to carry these substances deep into the Dhatus or tissues. Apart the Ghrita contains the phospholipids that play an important role in bone mineralization.

Madhu is the best vehicle to transport medicines as it possesses the capacity to go through micro channels. Main role of Madhu is to increase the retention time of Basti by counteract the irritative property of Saindhava. The retention time of irritative substance in rectum may be favored by making solution as nearly isotonic as possible by using colloidal fluid. Glucose atoms of
Honey have better porousness to get ingested and enter the circulation and are readily absorbed and assimilated by the body. In this way it energizes the body very quickly. Saindhva Lavana in Basti Dravya may play an important role in the absorption of the drug through $\mathrm{Na}$ channels, the most commonly used channels for the absorption of drugs. Kalka helps in disintegrate the malas by increasing osmotic permeability of the solution. Kalka drug enhances the action of Kawath Dravya and Kalka provide thickness to the Basti Dravya.

\section{CONCLUSION}

Asthi Kshaya are Asthi Dhatu Kshyajanya Roga and which may be co-related to osteoporosis of the modern science. The prevalence of Asthi Kshaya is more in people aged above 40 years It is understood that peak adult bone mass grows at a average age of 30-35 years and eventually the bones gradually lose their mineral content. Asthi Kshaya is more prevalent in people with dominant in Vata Prakruti, because Vata is the responsible for Asthi Kshaya. Ksheera Bastis are best Rasayana, Brimhana as they contain Ksheera and Ghrita, which according to our Acharyas are considered as Nitya Rasayana. Ksheera Basti nourishes the Asthi Dhatu and there by pacifies its Ashrayee Vata Dosha. 15 patients of Asthikshaya were treated with Panchtikta Ksheera Basti i.e. (Group A). This therapy has provided extremely significant relief in all subjective parameters and objective parameters. 15 patients of $A s$ thikshaya were treated with Asthi Sandhaniya Dravya Siddha Ksheera Basti i.e. (Group B). This therapy has provided extremely significant relief in Asthi Shoola (Bone Pain), Sandhi Shoola (Joint Pain), Sparsashayata Dourbhalya/Sharma, Rukshya and BMD and Very significant result is found in Keshapatan.

The percentage relief of Panchtikta Ksheera Basti on symptoms of Bone pain etc. shown better results in comparison to Asthi Sandhaniya Darvya Siddh Ksheera Basti. On comparing the effects on BMD it was found both Group have showed similar improvements there is not significant results in the effects of therapies in Group A and Group B on BMD. This indicates that Group- A \& B, had similar therapeutic effect. 
The treatment was more effective in the subjective parameters Asthi Shoola, Sandhi Shoola, Dourbalya / Shrama, Rukshyta, Asthi Sparshaasahyata, Kesha Patina, in comparison to objective parameters like BMD tScore.

Therefore it can be concluded that the Chikitsa Sutra revealed by Acharyas for Asthikshaya thousands of years ago i.e. the use of Basti prepared with the combination of Ksheera, Ghrita and Tikta Dravya and the use of Sandhaniya Dravya which Sandhana in nature and prevent Bhagna of Asthi It promotes the union of interrupted Dhatus, so that Sandhaniya Dravya is effective even today.

\section{REFERENCES}

1. Kaviraja Atrideva Gupta, Vagbhata, Asthtanga Hridaya, with the Vidyotini Hindi commentary, Chaukhamba Orientalia, Varanasi, Reprint Edition: 2016, Sutrasthana chapter 11, Shloka 26-28 p.117.

2. Pt. Kasinatha Sastri and Dr. Gorakha Natha Chaturvedi, Charaka Samhita of Agnivesha, Chaukhambha Bharati Academy, Varannsi; Reprint Edition :2013, vol.1, Sutra Sthana chapter 17, Shloka 67 p. 348.

3. Pt. Kasinatha Sastri and Dr. Gorakha Natha Chaturvedi, Caraka Samhita of Agnivesha, Chaukhambha Bharati Academy, Varanasi; Reprint Edition :2013, vol.1, Sutra Sthana chapter 28, Shloka 27 p. 573.

4. Consensus development conference: diagnosis, prophylaxis, and treatment of osteoporosis. Am J Med 1993;94: 646-50.

5. John. P. Bilezikian et.al. Endocrinology and metabolism clinics of North America, Osteoporosis, Saunders Philadelphia, 2004. 14. Singh.

6. Pt. Kasinatha Sastri and Dr. Gorakha Natha Chaturvedi, Charaka Samhita of Agnivesha, Chaukhambha Bharati Academy, Varannsi; Reprint Edition :2013, vol. II Siddhi Sthana chapter 1, Shloka 39 p. 971.

7. Kaviraja Ambikadutta Shastri Edited Susruta Samhita, Chaukhambha Sanskrit Sansthan, Varannsi; Reprint Edition:2013, vol 1, Chiktisa Sthana chapter 35, Shloka 25 p. 192.

8. Bhisagacharya Harishastri, Vagbhata, Asthtanga Hridaya, with the commentaries 'Sarvangasundara' of Arunadatta and Ayurvedarasayana of Hemadri, Chaukhamba Orientalia, Varanasi, Reprint Ninth Edition: 2005, Sutrasthana chapter 11, Shloka 31 p.187.
9. Dr Brahmanand Tripathi, Shrangdhara Samita Of Agnivesha Chaukhambha Surbharti Parkashan, Varannsi; Edition :2016, Proova Khanda, Chapter 4 Shloka 18 p.35.

10. Kadlimatti S, Subbana G. (2009). Clinical evaluation of the role of Tiktaksheerabasti and Ajasthi Bhasma in the management of Asthi Kshaya vis-àvis Osteoporosis. An International Quarterly Journal of Research in Ayurveda, Ayu-Vol. 30, No. 2 (April-June) 2009, pp. 131141.

11. Rani Khushboo (2018) Osteoporosis with Tikta Ksheer Basti Chikitsa -A Case Study, An International Journal of Research in AYUSH and Allied Systems, Ayushdhara, May - June 2018 | Vol 5 | Issue 3.

12. Sembulingam, K., \& Sembulingam, P. (2010). Parathyroid Glands and Physiology of Bones. In Essentials of Medical Physiology (5th ed.). New Delhi, IN: Jaypee Brother Medical Publishers (P) LTD. p. 391.

13. Pt. Kasinatha Sastri and Dr. Gorakha Natha Chaturvedi, Charaka Samhita of Agnivesha, Chaukhambha Bharati Academy, Varannsi; Reprint Edition :2013, vol.1, Sutra Sthana chapter 4, Shloka 5 p. 75.

\section{Source of Support: Nil \\ Conflict of Interest: None Declared}

How to cite this URL: Sunita Bola et al: A Comparative Clinical Study Of Panchtikta Ksheera Basti And Asthi Sandhaniya Dravya Siddh Ksheera Basti In Asthi Kshaya (Osteoporosis). International Ayurvedic Medical Journal \{online\} 2020 \{cited November, 2020\} Available from: http://www.iamj.in/posts/images/upload/2554_2562.pdf 